\title{
Cimetidine - antacid combination as premedication for elective Caesarean section
}

The effect of premedication with an oral antacid (magnesium trisilicate), oral cimetidine or a combination of both was studied in 80 parients undergoing elective Caesarean section. Twenty patients served as untreated controls. Seventy per cent of the patients were in the high risk range for acid aspiration pneumonitis $(\mathrm{pH}<2.5$ plus gastric content volume $>25 \mathrm{~m} / \mathrm{l}$. Antacid therapy was effective in raising $\mathrm{pH}$ but the gastric volume remained high in 50 per cent of the patients. Cimetidine was effective in decreasing gastric volume and raising $p H$ but the $p H$ was still $<2.5$ in two patients. None of the patients given the cimetidine-antacid combination were in the high risk range for acid aspiration pneumonitis. The combination of an oral dose of cimetidine $400 \mathrm{mg}$, three to four hours before the operation followed by $20 \mathrm{ml}$ of magnesium tristicate one hour preoperatively proved to be the most efficacious regimen for prophylaxsis against Mendelson's syndrome in elective Caesarean section. Recena reports have suggested that non-particulate antacids (e.g., sodium citrate) may be preferable to purticulate antacids such as magnesium trisilicate.

\section{Key words}

PREMEDICATION: cimetidine; COMPLICATIONS: lung acid aspiration, prophylaxsis; ANAESTHESIA: obstetric, Caesarean section.

From the Department of Anaesthesia, Maternity Hospital, Kuwait.

Address correspondence to: Dr. A.S. Okasha, Anacsthesia Department, Faculty of Medicine, University of Alexandria, Alexandria, Egypt.
Acid pulmonary aspiration (Mendelson's syndrome) is a major cause of anaesthesia related morbidity and mortality. ${ }^{1}$ The risk is greatest in patients with large volumes of gastric contents of $\mathrm{pH}$ less than 2.5, as in obstetric patients. Antacid therapy for prophylaxsis against Mendelson's syndrome is established in obstetric and other emergency anaesthesia. ${ }^{2}$ Recently, cimetidine, a competitive histamine $\mathrm{H}_{2}$-receptor antagonist which inhibits gastric secretion, was advised as a preoperative single oral dose for prophylaxsis against Mendelson's syndrome. The aim of this study was to compare the effects of preoperative oral cimetidine, oral antacids and a combination of cimetidine and antacids on the $\mathrm{pH}$ and volume of gastric contents at the time of induction of anaesthesia in patients undergoing elective Caesarean section.

\section{Methods}

The study was carried out on 80 healthy patients scheduled to receive general anaesthesia for elective Caesarean section. Patients were selected for the study only if they had no pre-existing gastrointestinal diseases. Informed consent was obtained from each patient before the study. All patients were kept fasting for at least eight hours prior to their operations and received only $0.6 \mathrm{mg}$ atropine given intramuscularly one hour before the operation. The patients were divided into four groups each comprising 20 patients.

1. Control group, received only atropine as premedication.

2. Cimetidine group, received a single oral dose of cimetidine $400 \mathrm{mg}$ ( 2 tablets) with no more than $20 \mathrm{ml}$ water three to four hours before induction of anaesthesia.

3. Antacid group, received $20 \mathrm{ml}$ magnesium 
trisilicate mixture orally one to two hours prior to the induction of anaesthesia.

4. Combined cimetidine-antacid group, received a single oral dose of $400 \mathrm{mg}$ cimetidine three to four hours before anaesthesia followed by $20 \mathrm{ml}$ magnesium trisilicate mixture one to two hours before induction of anaesthesia.

A standard anaesthesia technique was utilized in all patients, consisting of a rapid sequence induction with thiopentone $3 \mathrm{mg} \cdot \mathrm{kg}^{-1}$ and succinylcholine $100 \mathrm{mg}$ administered intravenously to facilitate tracheal intubation. Anaesthesia is maintained with nitrous oxide 50 per cent with oxygen and after delivery of the baby intermittent doses of pentazocaine were given. Muscle relaxation was obtained with d-tubocurarine as necessary and intermittent positive pressure ventilation was administered using a Manley ventilator.

After induction of anaesthesia, a gastric tube was passed through the mouth into the stomach and $5 \mathrm{ml}$ of gastric fluid were removed for $\mathrm{pH}$ determination. Fifty $\mathrm{ml}$ of one per cent polyethylene glycol (PEG) were then injected into the stomach for determination of gastric volume by the dilution method. ${ }^{4}$ The PEG, a nontoxic, nonabsorbable, water soluble polymer, was mixed with the gastric fluid by aspiration and reinjection several times. After mixing, the diluted gastric contents were removed as complete as possible. ${ }^{4}$ The $\mathrm{pH}$ of the gastric fluid was measured by a Pye Model $290 \mathrm{pH}$ metre. The PEG concentration in the diluted gastric content was determined by a turbidimctric method ${ }^{5}$ and the volume of fluid from the stomach diluting the PEG was calculated.

Student's t-test for independent means was used to compare the characteristics of test groups and the volume of gastric contents. Because of the logarithmic nature of the $\mathrm{pH}$ scale, medians rather than average values are given, and ranges of $\mathrm{pH}$ values were compared with the Mann-Whitney test.

\section{Results}

The four groups of the studied patients were similar in age, weight and preoperative fasting period (Table I). The volumes and $\mathrm{pH}$ values of the gastric aspirate are shown in Table II. A marked reduction was found in the acidity of the gastric contents in the groups which received either magnesium trisilicate, cimetidine or a combination of both, compared to the control group (Mann-Whitney $p<0.003$ ). The
TABLEI Patient characteristics

\begin{tabular}{llll}
\hline Group & $\begin{array}{l}\text { Age } \\
\text { (Years) }\end{array}$ & $\begin{array}{l}\text { Weight } \\
(\mathrm{kg})\end{array}$ & $\begin{array}{l}\text { Time fasted } \\
\text { (hours) }\end{array}$ \\
\hline Control & $* 23-42$ & $54-86$ & $8-11$ \\
& $+35.5 \pm 3.9$ & $67.0 \pm 12.6$ & $9.6 \pm 0.6$ \\
Antacid & $25-43$ & $50-82$ & $8.5-12$ \\
& $37.0 \pm 6.2$ & $69.1 \pm 13.2$ & $9.2 \pm 0.6$ \\
Cimetidine & $22-49$ & $53-85$ & $8-13$ \\
& $36.6 \pm 3.5$ & $68.4 \pm 9.7$ & $10.5 \pm 0.9$ \\
Cimetidine & $20-46$ & $47-90$ & $8.5-14$ \\
+ antacid & $34.4 \pm 5.4$ & $70.2 \pm 15.3$ & $10.3 \pm 1.2$ \\
\hline
\end{tabular}

*Range.

tMean $\pm \mathrm{SD}$

mean volume of gastric contents was significantly reduced in the treated groups compared with the control group. It is reduced to 40.7 per cent in the cimetidine group $(\mathrm{p}<0.005)$, to 51.6 per cent in the cimetidine-antacids combination group $(\mathrm{p}<$ 0.005 ) and to 80.7 per cent in the antacid group ( $\mathrm{p}<$ $0.05)$.

In Table III, the characteristics of the gastric contents in the four groups are shown. The patients at risk of developing acid aspiration pneumonitis ( $\mathrm{pH}<2.5$ and volume $>25 \mathrm{ml}$ ) were reduced from 70 per cent in the control group to zero in the other groups. Of the 20 patients in the control group, 18 had a $\mathrm{pH}$ less than 2.5 and 16 had a volume greater than $25 \mathrm{ml}$; this was more than $50 \mathrm{ml}$ in six patients. In the cimetidine group two patients showed $\mathrm{pH}$ values less than 2.5 . In the cimetidine-antacid combination group, only one patient showed a gastric content volume in excess of $25 \mathrm{ml}(38.5 \mathrm{ml})$.

TABLE II The volume and $\mathrm{pH}$ of gastric contents after induction of anaesthesia

\begin{tabular}{lll}
\hline Group & $\begin{array}{l}\text { Volume }(\mathrm{ml}) \\
(\text { mean } \pm S D)\end{array}$ & $\begin{array}{l}\mathrm{pH} \\
\text { (median and range) }\end{array}$ \\
\hline Control & $44.42 \pm 16.4$ & $\begin{array}{l}1.78 \\
(1.18-6.92) \\
7.08 \ddagger\end{array}$ \\
Antacid & $35.87 \pm 14.8^{*}$ & $\begin{array}{l}7.08 \ddagger \\
(3.9-8.23) \\
6.16 \dagger\end{array}$ \\
Cimetidine & $18.1 \pm 4.51 \dagger$ & $\begin{array}{l}(1.6-7.6) \\
7.19 \ddagger\end{array}$ \\
Cimetidine & $22.92 \pm 4.45 \dagger$ & $(3.45-8.32)$ \\
+ antacid & &
\end{tabular}

$* \mathrm{P}<0.05$ vs Control.

$\mathrm{tP}<0.005$ vs Control.

$\mathrm{tP}<0.003$ vs Control. 
TABLE III Distribution of gastric volumes and $\mathrm{pH}$

\begin{tabular}{lllll}
\hline Group & & $p H<2.5$ & Volume $>25 \mathrm{ml}$ & $p H<2.5$ and volume $>25 *$ \\
\hline Control & $(n=20)$ & $18(90 \%)$ & $16(80 \%)$ & $14(70 \%)$ \\
Antacid & $(n=20)$ & 0 & $10(50 \%)$ & 0 \\
Cimetidine & $(n=20)$ & $2(10 \%)$ & 0 & 0 \\
Cimctidine & $(n=20)$ & 0 & $1(5 \%)$ & 0 \\
+ antacid & & & & \\
\hline
\end{tabular}

${ }^{*}$ pH $<2.5$ and volume $>25=$ suggestcd risk valucs for acid aspiration pneumonitis.

\section{Discussion}

The smotional strain associated with hospitalization and apprehension about the forthcoming operation may disturb gastric motility and increase gastric acid secretion. ${ }^{6}$ Steroids, ACTH and epinephrine given in amounts similar to those released by the body under stress increase the amount and acidity of gastric secretion. ${ }^{7}$ The severity of the sequelae of pulmonary aspiration of gastric contents during anaesthesia depend mainly on the acidity and volume of the aspirate. Adult patients at risk for acid aspiration pneumonitis are defined as those having gastric juice of $\mathrm{pH}$ less than 2.5 and volume of more than $25 \mathrm{ml}^{8}$

The use of the PEG dilution method allows for a more accurate measurement of gastric volume than simple aspiration through a gastric tube ${ }^{4}$ As a result the volumes of gastric contents in the present study are substantially higher than those reported previously in patients undergoing Caesarean section.

In the present study we noted that 14 of the 20 patients (70 per cent) in the control group had sufficient acid gastric juice ( $\mathrm{pH}<2.4$ and volume $>25 \mathrm{ml}$ ) to cause acid pneumonitis if the total gastric volume was aspirated. Two of these patients had gastric volumes in excess of $70 \mathrm{ml}$. This indicates that many patients coming to the operative theatre have a large amount of acid gastric juice which if aspirated during anaesthesia may lead to a high degree of morbidity and even mortality.

In the antacid group, the $20 \mathrm{ml}$ dosage of magnesjum trisilicate given one to two hours before operation was effective in raising the gastric $\mathrm{pH}$ above 2.5 in all patients and no patient was potentially at risk of acid aspiration pneumonitis during induction of anaesthesia. ${ }^{9}$ Antacid prophylaxsis is a well-established practice in obstetric $c^{8}$ and outpatient anaesthesia ${ }^{9}$ although its beneficial effects on the morbidity of pneumonitis have not been proven. The nettralization of gastric contents is achieved reliably with antacids but it occurs at the cost of increased volume of the gastric contents. ${ }^{10}$ This was evident in our study, that although there was significant reduction of the gastric contents in the antacid group when compared with the control group, still ten patients had volume of gastric contents more than $25 \mathrm{ml}$. A regimen of two hourly administrations of $15 \mathrm{ml}$ of magnesium trisilicate mixture recommended by Crawford, has been reported to leave 20 per cent of patients "unprotected" during subsequent induction of anaesthesia. ${ }^{12}$ Some concern has also been expressed regarding the possible pulmonary toxicity of antacid aspiration itself. ${ }^{13}$ Recent reports have suggested that non-particular antacids (c.g., sodium citrate) may be preferable to particulate antacids.

Cimetidine is reported to reduce gastric volume and to raise $\mathrm{pH}$ by blocking gastric histamine receptors. ${ }^{14}$ It inhibits basal gastric acid secretion and antagonizes gastric acid stimulants. The present study showed that a single oral dose of $400 \mathrm{mg}$ cimetidine three to four hours before operation is effective in reducing the acidity and the volume of gastric contents. Although there was a significant increase in mean $\mathrm{pH}$ of the patients in the cimetidine group, two patients still had a pH less than 2.5. This may be because cimetidine acts on newly formed gastric secretions and not on material already present in the stomach, which may be highly acidic and may alter the $\mathrm{pH}$ of the newly secreted gastric juice. The cimetidine group showed a striking reduction in the mean volume of gastric contents, compared with the control and antacid groups. All the studied patients in the cimetidine group showed a volume of less than $25 \mathrm{ml}$. This study showed that cimetidine has a significant advantage over antacid in reducing the volume of the patients' gastric contents. Salmenpera et al. ${ }^{15}$ reported marked 
reduction in the volume of the gastric contents after cimetidine premedication. This is in contrast to previous reports $^{3.16}$ where no significant effects on gastric juice volumes were found after premedication with cimetidine.

We observed no adverse effects of cimetidine on the newborns. Wilson ${ }^{17}$ and Howe et al. ${ }^{18}$ found that cimetidine crossed to the foetal circulation fairly rapidly and was excreted by the foetus, at least partially unaltered into liquor amnii. These studies showed that the cimetidine level in the foetal blood is significantly lower than in maternal blood, which suggests some form of protein or fat binding in the mother. Follow up of the neonates in these studies revealed no evidence of drug induced pathology at discharge or, in some cases, months later. Wilson concluded that there is no significant pharmacological risk from the use of a single dosc of cimctidine in pregnant patients shortly before delivery. ${ }^{17}$

The present study showed that administration of a single oral dose of $400 \mathrm{mg}$ cimetidine three to four hours before operation followed by $20 \mathrm{ml}$ magnesium trisilicate one to two hours before operation is the most efficacious premedication for prophylaxsis against pulmonary aspiration syndrome and better than using antacids or cimetidine alone. Both the volume and acidity of gastric contents were suppressed to below the suggested critical values for acid aspiration pneumonitis. Only one patient had a volume larger than $25 \mathrm{ml}$.

In conclusion, this study suggests that combining the neutralizing effect of antacids with the marked reduction in gastric content acidity and volume produced by cimetidine, provides a useful and safe adjunct for patients considered to be at risk from potential acid aspiration.

\section{References}

1 Scott $D B$. Mendelson's syndrome - editorial. Br J Anaesth 1978; 50: 977.

2 Taylor $G$, Pryse-Davies $J$. The prophylactic use of antacids in the prevention of the acid-pulmonary aspiration syndrome (Mendelson's syndrome). Lancet 1966; 1: 288.

3 Husemeyer RP, Davenpors HT, Rajasekran T. Cimetidine as a single dose for prophylaxsis against Mendelson's syndrome. Anaesthesia, 1978; 33: 775.

4 Ong BY, Palhniuk RJ, Cumming M. Gastric volume and $\mathrm{pH}$ in out patients. Can Anaesth Soc J 1978; 25: 36.
5 Malawer SJ, Powell DW. An improved turbdimettic analysis of polyethylene glycol utilizing emulsifier. Gastroentrology 1967; 53: 250 .

6 Guyton AC. Textbook of Medical Physiology. Philadelphia: W.B. Saunders Co., p. 876, 1976.

7 Christensen KC, Stadil $F$. Effect of epinephrine and norepinephrine on gastric release and gastric secretion of acid in man. Scand J Gasiroenterology Supp] 1976; 37: 38 .

8 Roberts RB, Shirley MA. Reducing the risk of acid aspiration during Caesarean section. Anaesth Analg $1974 ; 58: 38$.

9 Cobb MJ, Stephen CR. Role of premedication in outpatient anaesthesia. Out patient anaesthesia, ed. Brown, B.R. Philadelphia, F.A. Davis Company, pp. 31, 1978.

10 Stoelting $R K$. Responses to atropine, glycopynolate and riopan of gastric fluid $\mathrm{pH}$ and volume in adult patients. Anesthesiology 1978 A; 48: 367.

11 Crawford JS. Anaesthesia for obstetrical emergencies, Br J Anaesth 1971; 43: 864.

12 White WD, Clark JM, Stanley-Lones GHM. The efficiency of antacid therapy, Br J Anaesth 1976; 48: 1117 .

13 Gibbs $C P$. Antacid pulmonary aspiration. Abstracts of the Society of Obstetric Anaesthesia and Perinatology meeting. Memphis, 1978.

14 Code $C F$. Reflections on histamine gastric secretion and the $\mathrm{H}_{2}$ receptor. N Engl J Med 1977; 296: 1459.

15 Salmenpera $M$, Kontila K, Kalima $T$. Cimetidine premedication, Acta Anaesthesiol Scand 1980; 24: 25 .

16 Keating PJ, BlackJF, Waston DW. Effects of glycopyrrolate and cimetidine on gastric volume and acidity in patients awaiting surgery. $\mathrm{Br} J$ Anaesth 1978: 50: 1247.

17 Wilson $J$. Effects of intravenous cimetidine on intragastric pH at Caesarean section. Amsterdam, Oxford Excerpta Medica, 1979; 185-90.

18 Howe JP, MoGowan WAW, Moore J, McGaughey $W$, Daundee JW. The placental transfer of cimetidine, Anaesthesia 1981; 36: 731 . 


\section{Résumé}

L'effet d' une prémédication avec un anti-acide oral (trisilicate de magnésium), la cimétidine ou une combinaison des deur médicaments a été étudiee chez quatre-vingt (80) patientes subissant une césarienne élective. Vingt (20) patientes nontraitées ont servi de contróle.

Soixante-dix des patientes du groupe contrôle auraient été dars la catégorie à haut risque s'il y avait eu aspiration $(\mathrm{pH}$ du liquide gastrique $<2.5$ et volume $>25 \mathrm{cc}$ ).

Les anti-acides ont été efficaces pour élever le $\mathrm{pH}$ mais le volume gastrique est demeuré élevé chez 50 pour cent des patientes recevant uniquement cette thérapie. La cimétidine fut efficace pour diminucr le volume gastrique et augmenter le $\mathrm{pH}$ mais celui-ci demeura inférieur à 2.5 chez deux patientes. Aucune des patientes recevant la combinaison des deux médicaments ne se trouvajent dans la carégorie d haut risque. La combinaisan de cimétidine orale $400 \mathrm{mg}$ donnée trois ou quatre heures avant la chirurgie et de trisilicate de magnésium $20 \mathrm{ml}$ donné une heure avant la chirurgie s'est révélée le régine le plus efficace pour la proplylaxie du syndrome de Mendelson associé à la césarienne. Des études récentes ont suggéré que des anti-acides non particulaires, par exemple citrate de soude, pourraient être préférables aux anti-acides particulaires comme le trisilicate de magnésium. 